NBER WORKING PAPER SERIES

\title{
INTERNATIONAL SPILLOVERS AND WATER QUALITY IN RIVERS: DO COUNTRIES FREE RIDE?
}

\author{
Hilary Sigman \\ Working Paper 8585 \\ http://www.nber.org/papers/w8585 \\ NATIONAL BUREAU OF ECONOMIC RESEARCH \\ 1050 Massachusetts Avenue \\ Cambridge, MA 02138 \\ November 2001
}

I am grateful to Defne Turker and Wenhui Wei for research assistance and to Howard Chang, Don Fullerton, Matthew Kahn, and seminar participants at George Mason University, the Harvard Kennedy School of Government, the NBER Summer Institute, Princeton University, Resources for the Future, Rutgers University, and the Yale School of Forestry and Environmental Studies for helpful comments. This research is supported in part by grant number SES-9876498 from the National Science Foundation. The views expressed herein are those of the author and not necessarily those of the National Bureau of Economic Research.

(C) 2001 by Hilary Sigman. All rights reserved. Short sections of text, not to exceed two paragraphs, may be quoted without explicit permission provided that full credit, including $\mathbb{C}$ notice, is given to the source. 
International Spillovers and Water Quality in Rivers: Do Countries Free Ride?

Hilary Sigman

NBER Working Paper No. 8585

November 2001

JEL No. Q2

\begin{abstract}
Transboundary spillovers may degrade environmental quality if countries free ride. This paper examines the extent of such degradation in water quality in international rivers. Using data from river monitoring stations in the UN's Global Emissions Monitoring System (GEMS), it compares pollution levels in international and domestic rivers. The results suggest that free riding may substantially increase pollution in international rivers, but the estimates are sensitive to the inclusion of country effects.
\end{abstract}

\author{
Hilary Sigman \\ Department of Economics \\ Rutgers University \\ 75 Hamilton Street \\ New Brunswick, NJ 08901-1248 \\ and NBER \\ sigman@econ.rutgers.edu
}


When pollution crosses national borders, polluting countries do not experience the full benefits of pollution control. As a result, they may not exercise sufficient control from an international perspective. Concern about such free riding has driven much analysis of global environmental issues, such as climate change and ozone depletion, and regional environmental issues, such as ocean degradation and acid rain. Under some circumstances, however, bargaining may result in explicit or implicit agreements that resolve the spillover problem. With efficient bargaining, pollution levels should not exceed their globally efficient level.

Although an extensive theoretical literature has developed on the conditions for international environmental agreements, only a few papers study countries' behavior in practice. This paper looks at the extent of free riding by comparing water quality in rivers in the presence and absence of spillovers. ${ }^{2}$ Data on water quality at monitoring stations on rivers around the world are from the United Nations' Global Emissions Monitoring System Water Quality Monitoring Project (GEMS/Water). I assemble supplemental data using both traditional country-level sources and a Geographic Information System (GIS) for data specific to the location of the monitoring stations. The pollution measure is biochemical oxygen demand (BOD), a widely measured and commonly generated form of water pollution.

The results provide some evidence that international spillovers cause degradation, suggesting that cooperation is incomplete at best. Stations upstream of international borders may have pollution levels elevated by $40 \%$ or more, especially when one excludes borders within the European Union (which appears to have less free riding). However, the results are very sensitive to the inclusion of country effects, indicating a need for caution in interpreting cross-country comparisons in pollution levels.

Several previous studies test the success of bargaining over international environmental quality using data on country-level emissions and information about the extent of the spillover. Murdoch and Sandler (1997b) study European sulfur air emissions (without a treaty), Murdoch, Sandler, and Sargent (1997) study European sulfur and nitrogen oxide air emissions (with and without a treaty), and Murdoch and Sandler (1997a) study global CFC emissions.

\footnotetext{
${ }^{2}$ I use the term "spillover" to refer to the physical effect of upstream countries' pollution on downstream pollution. This spillover should be distinguished from any elevated pollution attributable to free riding.
} 
In addition to addressing a different environmental medium, the current data provide some methodological advantages. This paper uses a monitoring station, rather than a country, as the level of analysis. Not all identification comes from country-level differences because countries may have monitoring stations on both domestic and international rivers. As a result, it is possible to include country effects to address unobserved country-level heterogeneity that may be correlated with environmental spillovers. Another advantage of rivers is that we can compare locations with and without spillovers and thus directly evaluate the extent of free riding; this situation distinguishes river pollution from many global or regional pollutants, which always involve spillovers. ${ }^{3}$

Countries have signed a handful of treaties pertaining to international rivers, although these treaties mostly address water withdrawal. The current study focuses on realized water quality rather than the decision to sign formal agreements. Countries may cooperate without explicit agreements or may sign treaties that do not constrain behavior, as Murdoch and Sandler's research suggests (see also Congleton, 1995). ${ }^{4}$ Similarly, some international law doctrines pertain to rivers, but these doctrines lack the enforcement threat of domestic laws and thus at best only facilitate negotiations.

The paper begins by discussing the GEMS data and the explanatory variables. Section 2 presents estimates of the effect of spillover and other determinants of river pollution. A brief conclusion follows.

\section{Data}

\subsection{Data on water quality}

The UN's Global Emissions Monitoring System Water Quality Monitoring Project (GEMS/Water) provides data on various water quality measures in rivers, lakes, and groundwater. This study

\footnotetext{
${ }^{3}$ Characterizing any elevated pollution in international rivers as free riding does not mean that it necessarily reflects the deviation from optimal pollution. Pollution levels may be suboptimal even in domestic rivers and other problems.

${ }^{4}$ In addition, it is difficult to find appropriate instruments for the endogenous decision to enter treaties. Conte Grande (1997) examines the influence of treaties on water quality in the GEMS data, using the political structure of the country to instrument for the presence of a treaty, and finds a beneficial effect of treaties on water quality.
} 
focuses specifically on the data for rivers. Annual average pollution levels are available for 1979-90, and triennial averages for 1988-96. ${ }^{5}$ Figure 1 shows the location of the 291 river monitoring stations (in 49 countries) that reported the pollutant studied here. Most stations do not report pollution in every year or triennial period: the median number of observations per station is 4 and $9 \%$ of stations report in only 1 year.

I use biochemical oxygen demand (BOD) as the pollution measure for several reasons. First, BOD is among the most common water quality measures in GEMS, providing many observations for analysis. Second, BOD levels are easily measured by standard procedures, which helps assure consistency in data quality across countries. Third, elevated BOD is attributable to a range of human activities, especially sewage, so heterogeneity in local industrial activity is not very important to BOD levels. Fourth, BOD may travel reasonably far downstream, allowing significant spillovers at many stations on international rivers. My rough calculation is that $34 \%$ of pollution at an average station upstream of a border will reach the border, with the remainder having attenuated naturally.

Table 1 reports means and standard deviations for the data used in the analyses. Observations have been divided according to whether they are from an international or domestic stations. In classifying a station as international, I consider all major tributaries (those included in the World Data Bank). Thus, even if the river does not cross into another country, I characterize the observation as international if water at this station has crossed or will cross an international border. ${ }^{6}$

Table 1 reports that average BOD concentrations in the sample are high. As an indication, rivers with BOD higher than $4 \mathrm{mg} / \mathrm{l}$ would not be acceptable for any recreational use (including boating) in the United States (Vaughan, 1986). International rivers appear to have higher pollution levels than domestic rivers. Although this difference is consistent with free riding, the two groups of stations differ along other dimensions as well, so more analy-

\footnotetext{
${ }^{5}$ Grossman and Krueger provide Annual data from 1979 through 1990. The Canada Centre for Inland Waters provides three-year averages from 1988 through 1996. I use annual data if available at a station for any year in a given period; otherwise I use the three year average. Time varying right-hand side variables are averaged over the relevant period if the dependent variable is a three year average.

${ }^{6}$ For about $20 \%$ of stations, the GEMS latitude-longitude did not place the station within 5 miles of a river in the World Data Bank. These problems may be because the GEMS locations are imprecise or the river was not included in the World Data Bank. These stations were classified based on the river name given in the GEMS data. The results were not sensitive to the exclusion of these stations.
} 


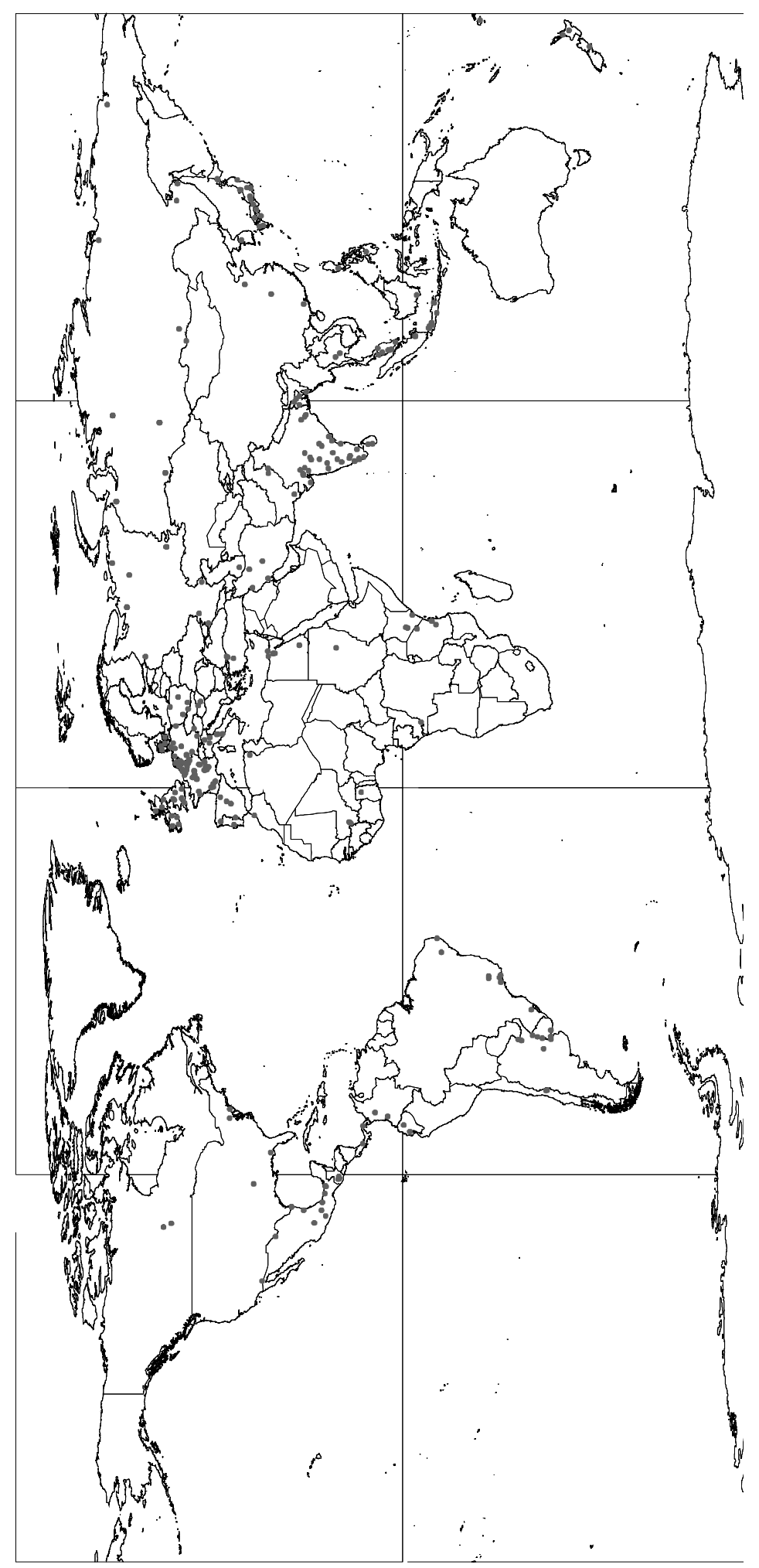

Figure 1: GEMS stations reporting Biochemical Oxygen Demand 
Table 1: Means and standard deviations of variables for international and domestic observations

\begin{tabular}{|c|c|c|c|c|}
\hline & \multicolumn{2}{|c|}{$\begin{array}{c}\text { Domestic } \\
\text { Obs }= \\
1093(64 \%) \\
\text { Stations }= \\
184(63 \%)\end{array}$} & \multicolumn{2}{|c|}{$\begin{array}{c}\text { International } \\
\text { Obs }= \\
587(36 \%) \\
\text { Stations= } \\
107(37 \%)\end{array}$} \\
\hline Water quality: & & & & \\
\hline Mean BOD concentration $(\mathrm{mg} / \mathrm{l})$ & 5.42 & $(14.57)$ & 7.39 & $(28.46)$ \\
\hline Number of measurements per observation & 15.56 & $(17.49)$ & 16.65 & $(16.90)$ \\
\hline Spillover measures: & & & & \\
\hline Border station & - & - & .16 & - \\
\hline Upstream station & - & - & .22 & 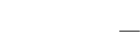 \\
\hline Downstream station & - & - & .71 & - \\
\hline Other determinants: & & & & \\
\hline Upstream population & .83 & $(2.94)$ & 1.36 & $(3.66)$ \\
\hline Upstream population data missing & .10 & - & 0 & - \\
\hline GDP per capita (thousand 1995 dollars) & 5.77 & $(4.93)$ & 7.27 & $(4.41)$ \\
\hline River physical characteristics: & & & & \\
\hline Flow $\left(\mathrm{m}^{3} / \mathrm{sec}\right)$ & 1253 & $(3956)$ & 4193 & $(8798)$ \\
\hline Flow data missing & .08 & - & .22 & - \\
\hline Deoxygenation rate, $k$ (days ${ }^{-1}$ ) & .48 & $(.24)$ & .39 & $(.15)$ \\
\hline
\end{tabular}

Notes: Based on observations when BOD was measured. Standard deviations reported for continuous variables only. 
sis is needed. Unfortunately, GEMS reports only a mean pollution level for measurements taken at different times during the year or three-year period, with little information about the timing of these measurements. The second row in Table 1 reports that these means are based on average of 16 measurements over the relevant period.

\subsection{Explanatory variables}

Several explanatory variables were added to the GEMS data. A few variables characterize the position of the station relative to international borders. The effects of spillovers may be different at stations upstream and downstream of international borders. Stations upstream of borders may have elevated pollution because the country exercises less pollution control than it would at comparable domestic locations. If downstream countries aggressively cut back their pollution in response to a high endowment of pollution from upstream, pollution levels observed at stations downstream of borders may be higher than in domestic rivers but lower than at upstream stations. Alternatively, if upstream countries free ride by moving polluting activities near their downstream borders, pollution levels would be elevated at stations downstream of the border, but might be depressed at stations upstream of the border.

Upstream and downstream stations may also differ because of strategic reporting. GEMS/Water aims to collect data from a representative set of river locations, including urban and rural settings, and a broad range of regions. Nonetheless, stations are chosen by participating countries, which may have strategic motives. If downstream countries wish to show their victimization, they may selectively report higher pollution levels. For example, they might manipulate results by choosing particularly dirty locations for stations or taking measurements on particularly dirty days. However, upstream countries have the reverse incentives.

To test for these effects, I distinguish upstream and downstream stations. Table 1 shows the frequency of observations in these locations. There are more observations at stations downstream of borders than upstream of borders, which might reflect an effort to hide free riding or a tendency to monitor rivers at lower reaches, where they are more dramatic landscape features. In addition to stations upstream and downstream of borders, some stations are located on a river when it forms a border between two countries. For border 
rivers, countries play both the downstream and upstream roles. Of international stations, $16 \%$ are on borders. ${ }^{7}$

The analysis also includes several other determinants of river water quality. As a measure of uncontrolled pollution levels at the station, the equations include the total population upstream of this station in 1994. I used a GIS to construct this variable from the 1994 Gridded Population of the World (Tobler et al., 1995) and data on flow direction from the US Geologic Survey's global Hydro1K database. ${ }^{8}$ This variable is intended to capture differences in the level of human influence on a river that might be related to the river's size and thus its international status. As expected, stations on international rivers have somewhat larger upstream populations than stations on domestic rivers.

National per capita income also may affect the costs of pollution control and the benefits of water quality. Summers and Heston's database provides annual income levels standardized for cross-country comparisons (Summers and Heston, 1991). ${ }^{9}$ Some previous studies have found that pollution rises and then falls with income, a pattern sometimes called the "environmental Kuznets curve." 10 As Table 1 reports, income is high in the sample as a whole and higher for international observations than domestic observations, perhaps because a large number of international observations are in Europe.

Finally, variables are included to reflect the effect of a given amount of waste input on water quality in the river. First, the river flow determines dilution rates and thus the effect of a given amount of waste on in-stream pollution concentrations. Table 1 reports the mean

\footnotetext{
${ }^{7}$ I use the border classification only for situations where the river forms a border at the point where the station is located. If the river forms a border up or downstream of the monitor, I code the bordering countries as upstream or downstream countries.

${ }^{8}$ I used ArcView's flow accumulation function with cells weighted by their population to calculate these values. The values are very noisy because the calculated location of the river often does not correspond to its actual location. However, these miscalculations do not seem to introduce any systematic bias from the perspective of the current analysis. The GIS produced no value for a few stations on islands (for example, New Zealand), which were beneath the resolution of the geographic data, and for one Iranian station, which latitude-longitude data place it in the middle of the Caspian Sea. A dummy variable is included for these missing observations.

${ }^{9}$ After 1992, Summers and Heston data are not available. I use World Bank income measures to scale the last year of Summers and Heston data to represent later years. For stations on borders, it seems arbitrary to use GDP variables for the monitoring country rather than the country across the river. Instead, I assigned border stations the average of the two countries' values.

${ }^{10}$ See Selden and Song (1994) and Grossman and Krueger (1995) for early work indicating this relationship. More skeptical perspectives about the empirical relationship can be found in Harbaugh et al. (2000) and Bradford et al. (2000).
} 
of this variable when available and a dummy variable for its absence (used in the regressions to avoid restricting the sample). International rivers have dramatically greater flow than domestic rivers, not only at the mean shown in the table, but also at the median.

Second, rivers vary in the speed of attenuation of pollutants. The time rate of exponential decay of BOD (known as the deoxygenation rate, $k$ ) is used as a measure of the speed of natural attenuation. I calculated this value from the GEMS data on river flow and temperature, using nonlinear functions from a survey of the scientific literature (Bowie et al., 1985).

\section{Estimates}

This section presents estimates of the effects of spillovers on pollution levels. The estimated equations have the form:

$$
\log b_{i t}=g\left(S_{i}, P O P_{i t}, G D P_{i t}, f_{i}, k_{i t}, c_{i}, t\right)+\epsilon_{i t}
$$

where $b_{i t}$ is the mean pollution concentration at station $i$ in year $t, S_{i}$ is a vector of measures of the spillover, $P O P_{i t}$ is upstream population, $G D P_{i t}$ is annual per capita GDP, $f_{i}$ is river flow, $k_{i t}$ is the deoxygenation rate, and $c_{i}$ is a country effect. A trend, $t$, is included to capture changes over time in pollution control technologies and environmental preferences.

A log-log functional form was chosen for equation (1) because factors that affect the uncontrolled pollution levels, such as upstream population and river flow, should have effects that are multiplicative with spillover effects. There are two exceptions to the $\log -\log$ specification. GDP variables enter the equation with a quadratic in levels to follow the specifications used in earlier work. The deoxygenation rate, $k_{i t}$, enters in levels because of the exponential decay function for BOD.

The error, $\epsilon_{i t}$, has a few characteristics that are taken into account in the estimation. First, BOD levels for any observation are the mean of multiple measurements. Because differences in monitoring frequency will result in heteroskedastic errors, the equations are estimated by weighted least squares with the number of measurements as weights. Second, 
errors at a single station across multiple years are likely to be correlated. ${ }^{11}$ To address this problem, the standard errors are adjusted for clustering at the station level. Models with station-level random effects yielded similar results to those reported here. ${ }^{12}$

Table 2 presents estimates of equation (1). I discuss the spillover variables first and then the remaining determinants of water quality.

Effects of spillovers. The first equation in Table 2 excludes country effects. This approach takes full advantage of the variability in the data, allowing observations in countries with all international or all domestic stations to influence the results. The coefficient of .352 in the first row implies that BOD levels are $42 \%$ higher at stations upstream of borders than other comparable stations. This effect is statistically significant at the $5 \%$ level. Stations on border rivers also had statistically significantly higher pollution.

Downstream location has a statistically insignificant positive coefficient. The point estimate on downstream location is smaller than upstream location, which could arise if downstream countries take mitigating actions against upstream free riding. However, the difference in these point estimates is not statistically significant. The lower point estimate on downstream location is inconsistent with strategic reporting and thus should at least diminish this concern.

However, there may be sources of country heterogeneity other than GDP that are related to the location of monitoring stations. The second column in Table 2 reestimates the equation with the addition of country effects. ${ }^{13}$ When country effects are included, all of the coefficients on the location variables become negative and not statistically significant at $5 \%$. In addition to country heterogeneity, lack of information may contribute to the change in the results. With the inclusion of the country effects, the coefficients are identified entirely

\footnotetext{
${ }^{11}$ We might wish to include fixed effects at the monitoring station level, as for example in Henderson's (1996) study of ozone. However, the variables of interest do not vary over time at a station, so there is no way to identify them separately from station effects.

${ }^{12}$ There is also the possibility of river-level correlations because some river systems have multiple monitoring stations (e.g., the Nile). Estimating the model with river-basin random effects did not much change the point estimates and made it difficult to address station-level clustering. Because the vast majority of stations are alone in their river basin, river-basin fixed effects required dropping a very large number of stations.

${ }^{13}$ For nonborder stations, the analysis includes dummy variables for the country in which the station is located. For border stations, each neighboring country is assigned a value of .5 to allow an average of the two countries' effects.
} 
Table 2: Weighted least squares estimates

\begin{tabular}{|c|c|c|c|c|}
\hline & \multicolumn{4}{|c|}{$\begin{array}{c}\text { Dependent variable: } \\
\text { Log (Mean BOD conc.) }\end{array}$} \\
\hline Country effects? & No & Yes & No & Yes \\
\hline Upstream station & $\begin{array}{r}.352 \\
(.158)\end{array}$ & $\begin{array}{r}-.230 \\
(.318)\end{array}$ & $\begin{array}{r}.750 \\
(.210)\end{array}$ & $\begin{array}{r}.420 \\
(.156)\end{array}$ \\
\hline EU upstream station & - & - & $\begin{array}{r}-.808 \\
(.313)\end{array}$ & $\begin{array}{r}-1.03 \\
(.491)\end{array}$ \\
\hline Downstream station & $\begin{array}{r}.166 \\
(.130)\end{array}$ & $\begin{array}{r}-.089 \\
(.114)\end{array}$ & $\begin{array}{r}.085 \\
(.126)\end{array}$ & $\begin{array}{r}-.144 \\
(.119)\end{array}$ \\
\hline EU downstream station & - & - & $\begin{array}{r}-.027 \\
(.217)\end{array}$ & $\begin{array}{r}.141 \\
(.200)\end{array}$ \\
\hline Border station & $\begin{array}{r}.419 \\
(.166)\end{array}$ & $\begin{array}{r}-.151 \\
(.198)\end{array}$ & $\begin{array}{r}.455 \\
(.218)\end{array}$ & $\begin{array}{r}-.304 \\
(.218)\end{array}$ \\
\hline EU border station & - & - & $\begin{array}{r}-.074 \\
(.237)\end{array}$ & $\begin{array}{r}.365 \\
(.243)\end{array}$ \\
\hline EU station & - & - & $\begin{array}{r}.466 \\
(.154)\end{array}$ & - \\
\hline Log(Upstream population) & $\begin{array}{r}.042 \\
(.021)\end{array}$ & $\begin{array}{r}.067 \\
(.023)\end{array}$ & $\begin{array}{r}.040 \\
(.021)\end{array}$ & $\begin{array}{r}.065 \\
(.023)\end{array}$ \\
\hline Upstream population missing & $\begin{array}{r}-.223 \\
(.299)\end{array}$ & $\begin{array}{r}-.785 \\
(.249)\end{array}$ & $\begin{array}{r}-.164 \\
(.296)\end{array}$ & $\begin{array}{r}-.696 \\
(.224)\end{array}$ \\
\hline GDP per capita & $\begin{array}{r}.094 \\
(.062)\end{array}$ & $\begin{array}{r}.099 \\
(.064)\end{array}$ & $\begin{array}{r}.088 \\
(.063)\end{array}$ & $\begin{array}{r}.147 \\
(.059)\end{array}$ \\
\hline GDP per capita squared & $\begin{array}{r}-.006 \\
(.003)\end{array}$ & $\begin{array}{c}-.004 \\
(.003)\end{array}$ & $\begin{array}{r}-.007 \\
(.003)\end{array}$ & $\begin{array}{r}-.006 \\
(.003)\end{array}$ \\
\hline $\log ($ Flow $)$ & $\begin{array}{r}-.083 \\
(.029)\end{array}$ & $\begin{array}{r}-.040 \\
(.029)\end{array}$ & $\begin{array}{r}-.061 \\
(.028)\end{array}$ & $\begin{array}{r}-.030 \\
(.030)\end{array}$ \\
\hline Flow missing & $\begin{array}{r}.146 \\
(.318)\end{array}$ & $\begin{array}{r}.063 \\
(.441)\end{array}$ & $\begin{array}{r}.221 \\
(.348)\end{array}$ & $\begin{array}{r}.161 \\
(.447)\end{array}$ \\
\hline Deoxygenation rate, $k$ & $\begin{array}{r}.718 \\
(.512)\end{array}$ & $\begin{array}{r}.434 \\
(.464)\end{array}$ & $\begin{array}{r}.860 \\
(.507)\end{array}$ & $\begin{array}{r}.464 \\
(.447)\end{array}$ \\
\hline Year & $\begin{array}{r}.022 \\
(.008)\end{array}$ & $\begin{array}{r}-.005 \\
(.006)\end{array}$ & $\begin{array}{r}.024 \\
(.008)\end{array}$ & $\begin{array}{r}-.005 \\
(.006)\end{array}$ \\
\hline Intercept & $\begin{array}{r}-1.15 \\
(.659) \\
\end{array}$ & - & $\begin{array}{r}-1.47 \\
(.670) \\
\end{array}$ & - \\
\hline $\mathrm{R}^{2}$ & .15 & .37 & .17 & .38 \\
\hline
\end{tabular}

Notes: Number of observations: 1680; Number of stations: 291.

Weighted by number of measurements.

Standard errors (in parentheses) robust to clustering at the station level. 
from variation within the small number of countries with both types of stations.

Another possible explanation for failing to find statistically significant effects with country effects is that these effects eliminate some of the relevant variation. If countries set environmental policies at a national level, they may not adjust pollution levels downward on individual stretches of river where a spillover occurs. Free riding would take the form of higher national pollution levels for countries with shared rivers than for those with only domestic rivers. If so, the country effect might pick up the effects of free riding as well as other country level heterogeneity. To test for this possibility directly, an equation was estimated with variables indicating if any of the country's rivers (including those without GEMS stations) were upstream of another country or on a border. Neither coefficient was statistically significant, although inclusion of these variables did make the coefficients on the upstream and border variables statistically insignificant.

The next two columns in Table 2 distinguish stations within the European Union (EU) from other international stations because EU institutions might reduce free riding. Column 3 includes four new variables, indicating a station (1) in an EU country and upstream of an EU country; (2) in an EU country and downstream of an EU country, (3) on the border between EU members; and (4) in an EU country. Column 4 conducts a similar comparison, but with country level effects.

These equations continue to find elevated pollution levels at upstream stations. For stations upstream of borders external to the EU, the coefficient of .75 in column 3 represents $111 \%$ higher pollution and the coefficient of .42 in column 4 corresponds to $52 \%$ higher pollution. It is important to note that the effect for non-EU upstream stations in column 4 is identified by very few observations, however, so it should be interpreted more as support for the positive effect found in column 3 than as a stand alone estimate.

Stations upstream of borders within the EU have statistically significantly less free riding than those upstream of non-EU borders both with and without country effects. In both equations, the estimate of the net effect of upstream stations within the EU (adding the coefficients on upstream stations and EU upstream stations) is negative, but this negative effect is not statistically significant. We cannot reject the absence of free riding at upstream stations within the EU, although we can reject it outside. Thus, the results provide some 
evidence that EU institutions successfully curb free riding.

For stations on borders, non-EU stations have a positive and statistically significant coefficient without country effects, but a negative and statistically insignificant coefficient with country effects. EU border stations do not have statistically lower pollution than non-EU border stations. For downstream stations, neither EU nor non-EU border stations exhibit statistically significantly higher pollution in the column 3 or 4 . The coefficient on the dummy variable for stations within the EU is statistically significant and (somewhat surprisingly) positive in column 3 .

Other determinants of water quality. The remaining coefficients in Table 2 provide information about other factors that affect the costs and benefits of water quality. Upstream population has a positive and statistically significant coefficient. With country effects, the elasticity of pollution to upstream population is .07, so pollution levels rise much less than proportionally with population. Perhaps some of the upstream population is too distant to alter pollution significantly at the stations. ${ }^{14}$

The GDP coefficients always appear to follow an inverted U-shaped pattern, but are jointly statistically significant at $5 \%$ only in the columns 3 and 4 . The maximum pollution occurs at per capita GDP of $\$ 12,000$ (column 3) and $\$ 11,000$ (column 4), approximately double the peak for BOD found by Grossman and Krueger.

The river flow rate enters with a negative coefficient, which is consistent with dilution. However, this coefficient is only statistically significant in the equations without country effects. The deoxygenation rate, $k$, has a positive point estimate, which is inconsistent with lower pollution when natural BOD decay occurs more rapidly. However, the coefficient is also not statistically significant at $5 \%$ in any of the equations in Table 2 .

Finally, the time trend is positive and statistically significant without country effects, but not statistically significant with country effects. This change probably reflects expansion over time of GEMS participation to include countries with lower environmental quality.

\footnotetext{
${ }^{14}$ The equations were also estimated with a local population measure, population within $20 \mathrm{~km}$, but including upstream population made the coefficient on local population statistically insignificant.
} 


\section{Conclusion}

My empirical analysis provides evidence that international spillovers significantly impair water quality in rivers. Stations upstream of international borders outside the EU have higher pollution than other stations. Stations on international borders may also exhibit higher pollution, but this effect is not robust to the inclusion of country effects. The EU appears to have successfully ameliorated free riding: one cannot reject that stations upstream of internal EU borders have typical pollution levels.

This evidence of free riding suggests that cooperation has not evolved between countries sharing rivers. Rivers would seem to represent a good case for cooperation because they involve small numbers of countries and their pollution has relatively well-defined benefits and costs. Thus, prospects for more difficult international environmental negotiations, such as those over greenhouse gases, would seem quite poor. However, the results for the EU may hold out some hope for successful international institutions. 


\section{References}

[1] Bowie, George L. et al. Rates, Constants, and Kinetics Formulations in Surface Water Quality Modeling (Second Edition), Washington, DC: U.S.EPA, 1985.

[2] Bradford, David F., Rebba Schlierckert, and Stephen H. Shore, "The environmental Kuznets curve: Exploring a fresh specification," Princeton University mimeo, 2000.

[3] Congleton, Roger D., "Toward a transactions cost theory of environmental treaties: Substantive and symbolic environmental agreements," Economia dell scelte pubbliche, 2-3 (1995), 119-139.

[4] Conte Grand, Mariana, "An empirical analysis of water pollution agreements," Chapter 3 in International Environmental Agreements, Unpublished Ph.D. Dissertation, UCLA, 1997.

[5] Grossman, Gene M. and Alan B. Krueger, "Economic growth and the environment," Quarterly Journal of Economics 110 (1995), 353-77.

[6] Harbaugh, William, Arik Levinson, and David Wilson, "Reexamining the empirical evidence for an environmental Kuznets curve," NBER Working Paper 7711, 2000.

[7] Henderson, J. Vernon, "Effects of air quality regulation" American Economic Review 86 (1996), 789-813.

[8] Murdoch, James C. and Todd Sandler, "The voluntary provision of a pure public good: The case of reduced CFC emissions and the Montreal Protocol," Journal of Public Economics 63 (1997a), 331-49.

[9] Murdoch, James C. and Todd Sandler, "Voluntary cutbacks and pretreaty behavior: the Helsinki Protocol and Sulfur Emissions," Public Finance Review 25 (1997b), 139-162.

[10] Murdoch, James C., Todd Sandler and Keith Sargent, "A tale of two collectives: Sulphur versus nitrogen oxides emission reduction in Europe," Economica 64 (1997), 281-301.

[11] Selden, Thomas M. and D. Song, "Environmental quality and development: Is there a Kuznets curve for air pollution?" Journal of Environmental Economics and Management 27 (1994), 147-62.

[12] Summers, Robert and Alan Heston, "The Penn World Table (Mark 5): An expanded set of international comparisons," Quarterly Journal of Economics 106 (1991), 327-68.

[13] Tobler, Waldo, Uwe Deichmann, Jon Gottsegen, and Kelly Maloy, "The Global Demography Project," National Center for Geographic Information and Analysis, UC Santa Barbara, Technical Report TR-95-6 (1995).

[14] Vaughan, William J., "The RFF Water Quality Ladder," Appendix B in Mitchell, Robert Cameron and Richard Carson, The Use of Contingent Valuation Data for Benefit/Cost Analyses in Water Pollution Control, Washington, DC: Resources for the Future, 1986. 